\title{
Pengembangan Media Komik dengan Model Problem Posing untuk Meningkatkan Kemampuan Pemecahan Masalah Matematika
}

\author{
Maulani Rizky Gumilang ${ }^{*}$, Wahyudi ${ }^{2}$, Endang Indarini ${ }^{3}$ \\ ${ }^{1,2,3}$ Universitas Kristen Satya Wacana Salatiga \\ *maulanirizkyg699@gmail.com
}

Diterima: Mei 2019. Disetujui: Juni 2019. Dipublikasikan: Juli 2019.

\begin{abstract}
ABSTRAK
Penelitian ini bertujuan untuk mengembangkan dan menguji kevalidan, kepraktisan, dan keefektifan media komik dengan model problem posing pada mata pelajaran matematika di sekolah dasar. Metode penelitian yang digunakan adalah R\&D dengan model pengembangan ADDIE. Kevalidan produk diperoleh melalui uji pakar dengan instrumen validasi pakar. Kepraktisan produk diperoleh melalui uji coba terbatas dengan instrumen angket. Keefektifan diperoleh melalui uji coba satu kelas dengan one grup pretest-posttest design kemudian hasilnya diuji menggunakan Paired Samples $T$ Test. Hasil dari penelitian ini adalah media komik dengan model problem posing untuk meningkatkan kemampuan pemecahan masalah matematika. Media pembelajaran dinyatakan valid berdasarkan hasil uji pakar media menunjukkan bahwa media komik termasuk kategori tinggi, pakar materi menilai media komik termasuk kategori tinggi, dan pakar pembelajaran menilai media komik termasuk kategori tinggi. Media pembelajaran dinyatakan praktis berdasarkan hasil angket respon siswa menunjukkan bahwa siswa dapat menggunakan media komik. Media pembelajaran juga dinyatakan efektif berdasarkan hasil Paired Samples $T$ Test pretest-posttest menunjukkan bahwa adanya perbedaan yang signifikan antara hasil belajar pada pretest dan posttest siswa.
\end{abstract}

Kata kunci: pengembangan, komik, problem posing, kemampuan pemecahann masalah.

\begin{abstract}
This study aims to develop and test the validity, practicality, and effectiveness of comic media with a problem-posing model on the subject of mathematics in elementary schools. The research method used was $R \& D$ with the ADDIE development model. The validity of the product was obtained through expert testing with expert validation instruments. The practicality of the product was obtained through limited trials using questionnaire instruments. Effectiveness was obtained through a one class trial with one group pretest-posttest design then the results were tested using the Paired Samples T Test. The results of this study are that comic media with problem-posing model improve mathematical problem-solving abilities. The learning media is declared valid based on the test results of media experts test showing that comic media is in the high category, material experts rate comic media as a high category, and learning experts rate comic media as a high category. Learning media are stated practical based on the results of the students' response questionnaires indicating that students can use comic media. Learning media are also declared effective based on the results of the Paired Samples T Test pretest-posttest which shows that there are significant differences between the learning outcomes at the pretest and posttest of student.
\end{abstract}

Keywords: development, comic, problem posing, problem solving ability.

How to Cite: Gumilang, M. R., Wahyudi, \& Indarini, E. (2019). Pengembangan Media Komik dengan Model Problem Posing untuk Meningkatkan Kemampuan Pemecahan Masalah Matematika. Journal Of Medives : Journal Of Mathematics Education IKIP Veteran Semarang, 3(2), 185-196. 


\section{PENDAHULUAN}

Setiap manusia menjalani kehidupan tentu tidak terlepas dari kata masalah. Masalah merupakan segala sesuatu yang terjadi di luar batas kemampuan seseorang, hal ini dapat dikatakan masalah apabila seseorang mengalami kesulitan dalam menyelesaikan serta membutuhkan pemikiran yang lebih (Rostika \& Junita, 2017). Selain itu, masalah dapat berupa suatu pertanyaan yang harus dijawab ataupun direspon. Namun tidak semua pertanyaan otomatis akan menjadi masalah. Suatu pertanyaan akan menjadi sebuah masalah apabila pertanyaan itu menunjukkan adanya tantangan (challange) yang tidak dapat dipecahkan dengan prosedur rutin (routine procedure) yang sudah diketahui oleh si pelaku (Lestari \& Sofyan, 2014). Maka dari itu, adanya suatu masalah yang dihadapi perlu diselesaikan melalui pemecahan masalah. Pemecahan masalah adalah suatu usaha untuk mendapatkan penyelesaian dari suatu masalah yang tidak rutin sehingga masalah tersebut dapat diselesaikan tanpa adanya kesulitan lagi (Wahyudi \& Anugraheni, 2017). Kemampuan pemecahan masalah sangat penting dalam pembelajaran, karena pembelajaran yang baik haruslah mengarah pada masalah yang sering ditemui dalam kehidupan sehari-hari maupun dekat dengan kehidupan siswa (Rostika \& Junita, 2017). Kemampuan pemecahan masalah sangat diperlukan siswa guna memenuhi kebutuhan yakni dalam memecahkan masalah serta mengembangkan diri mereka sendiri (Mulyati, 2016).
Kemampuan pemecahan masalah ditekankan pada kurikulum 2013 berbasis tema dimana mata pelajarannya terintegrasi. Pembelajaran tematik integratif terdapat pada pengembangan kurikulum yang baru dengan menggunakan satu tema yang mencakup beberapa mata pelajaran (Biliya, 2015). Namun untuk mata pelajaran matematika dan pendidikan jasmani olahraga (PJOK) sebagai mata pelajaran yang berdiri sendiri untuk kelas IV, V, VI berdasarkan Permendikbud No 24 Tahun 2016 (Kemdikbud, 2016b). Matematika merupakan mata pelajaran yang harus dipelajari siswa karena memuat ilmu yang bersifat universal dan memiliki hubungan erat dalam kehidupan nyata (Rostika \& Junita, 2017).

Kemampuan pemecahan masalah matematis merupakan salah satu kemampuan yang perlu dikuasai siswa saat belajar matematika (Riska \& MZ, 2018). Hal ini dapat dipelajari mulai dari usia sekolah dasar. Satuan pendidikan sebagai tempat untuk mengembangkan kemampuan siswa hendaknya melaksanakan proses pembelajaran secara interaktif, inspiratif, menyenangkan, menantang, memotivasi siswa untuk berpartisipasi aktif, serta memberikan ruang yang cukup bagi prakarsa, kreativitas dan kemandirian sesuai dengan bakat, minat dan perkembangan fisik serta psikologis sosial (Permendikbud Nomor 22 Tahun 2016 dalam Kemdikbud, 2016a). Hal tersebut tidak terlepas dari peran guru dalam proses pembelajaran yakni (1) guru sebagai demonstrator dengan melakukan penguasaan bahan dan materi 
yang akan diajarkan, (2) guru sebagai pengelola kelas dilakukan dengan penanganan pada struktur kelas, (3) guru sebagai mediator dan fasilitator, serta (4) guru sebagai evaluator dengan melakukan penilaian terhadap tujuan, materi serta metode yang digunakan (Rusman, 2011).

Adanya peran guru, diharapkan dapat menyiapkan anak didik untuk memiliki kecakapan pada abad ke-21 yakni dalam pelaksanaan pembelajaran mengarah pada keaktifan, kreatif, inovatif serta kemandirian dengan cara memberikan sebuah tantangan kepada siswa dalam memecahkan permasalahan yang ditemuinya dalam kehidupan sehari-hari dari hal sederhana ke arah yang kompleks. Salah satu solusi mengatasi permasalahan yakni dengan memanfaatkan teknologi yang ada serta mengarah pada prinsip-prinsip belajar yang berorientasi pada proyek dan permasalahan sampai aktivitas kolaboratif. Adanya hal tersebut diharapkan dapat menghasilkan sumber daya manusia yang berkualitas yang mampu menghadapi berbagai tantangan dan tuntutan yang bersifat kompetitif (Rusman, 2017).

Salah satu aspek yang sangat berpengaruh dalam tercapainya suatu kegiatan pembelajaran pada satuan pendidikan adalah model pembelajaran. Model pembelajaran adalah seluruh rangkaian penyajian materi ajar yang meliputi aspek sebelum, sedang dan sesudah pembelajaran yang dilakukan guru serta segala fasilitas yang terkait yang digunakan secara langsung atau tidak langsung dalam proses belajar mengajar (Istarani, 2015). Banyak model pembelajaran yang dapat dipilih guru untuk melaksanakan pembelajaran. Salah satunya model pembelajaran Problem Posing. Model problem posing adalah model pembelajaran yang memberikan kesempatan kepada siswa untuk membuat permasalahan (soal) sendiri dan menjawab dengan baik secara individu maupun kelompok (Inhar, 2016). Sintaks model problem posing dimulai dari guru menyampaikan tujuan pembelajaran, menjelaskan materi pelajaran dan media yang telah disiapkan, siswa dibimbing untuk membentuk kelompok, siswa dihadapkan dengan suatu permasalahan terkait dengan materi, dilanjutkan dengan siswa membuat soal kemudian menukar soal serta mengerjakan soal dari kelompok lain, terakhir mempresentasikan maupun memeriksa jawaban (Kuswanti, 2016).

Model problem posing akan diimplementasikan dalam proses pembelajaran dengan memanfaatkan penggunaan media pembelajaran. Media pembelajaran yang dikembangkan melibatkan aktivitas membaca yang didukung dengan ilustrasi gambar, tentunya aktivitas tersebut akan menciptakan suasana belajar yang menyenangkan.

Realitanya, media pembelajaran yang ada hanya mefokuskan pada hasil belajar. Berlainan dengan media pembelajaran yang dikembangkan peneliti mengarah pada kemampuan berfikir tingkat tinggi (HOTS), dimana siswa tidak hanya mengingat berdasarkan hafalan. Pada penelitian ini peneliti memilih media komik karena media komik mampu meningkatkan motivasi dan kualitas pada proses 
pembelajaran. Selain itu, media komik ditujukan untuk siswa kelas V Sekolah Dasar agar mampu menumbuhkan minat baca.

\section{METODE PENELITIAN}

Penelitian ini merupakan jenis penelitian $R \& D$ dengan model pengembangan ADDIE yang terdiri dari lima tahap yakni (1) analysis (analisis), (2) design (perancangan), development (pengembangan), implementation (implementasi), dan (5) evaluation (evaluasi). Secara jelas, tahapan model ADDIE dapat dilihat pada Gambar 1.

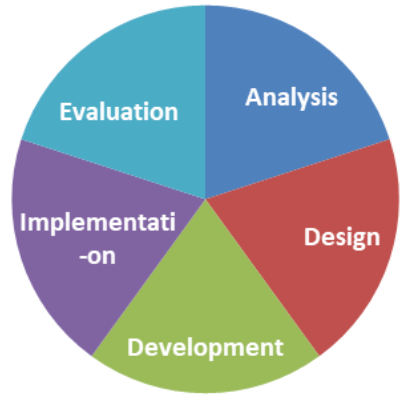

Gambar 1. Model Pengembangan ADDIE

Berdasarkan Gambar 1 mengenai 5 tahap model pengembangan ADDIE, secara rinci dapat dijelaskan sebagai berikut.

\section{Analysis (Analisis)}

Peneliti melakukan tahap analisis dari hasil wawancara dengan guru, angket untuk siswa, serta wawancara dengan siswa. Wawancara dengan guru dilakukan untuk mengetahui proses pembelajaran dan media pembelajaran yang pernah digunakan. Angket siswa dilakukan untuk mengetahui kemampuan awal siswa dalam menggunakan media pembelajaran yang berkaitan dengan aktivitas membaca buku cerita dan materi pada mata pelajaran matematika. Selain itu, peneliti melakukan wawancara dengan siswa untuk mengetahui kebutuhan siswa mengenai kemampuan pemecahan masalah.

Subyek dalam penelitian ini adalah guru dan siswa kelas V SD Negeri Gendongan 02, Kecamatan Tingkir, Kota Salatiga. Peneliti memilih subyek tersebut dengan berbagai pertimbangan yakni SD Negeri Gendongan 02 termasuk SD unggulan di kota Salatiga, jumlah siswanya mencukupi, guru dan siswanya sudah terbiasa melakukan kegiatan pembelajaran dengan berbagai model pembelajaran dan SD tersebut sering kali digunakan untuk penelitian.

\section{Design (Perancangan)}

Peneliti melakukan tahap design (perancangan) melalui 5 langkah. Langkah pertama yaitu menentukan judul dan tema media pembelajaran berupa komik. Langkah kedua dengan menyiapkan sumber dari buku maupun referensi lain yang mendukung. Langkah ketiga dengan melakukan identifikasi terhadap Kompetensi Dasar pada aspek kognitif dan aspek keterampilan. Langkah keempat dengan melakukan identifikasi pada indikator pencapaian kompetensi serta membuat bentuk penilaian yang akan disajikan. Langkah terakhir dengan merancang media pembelajaran berupa komik dan menyusun rencana pelaksanaan pembelajaran (RPP) terkait dengan langkah model pembelajaran yang digunakan.

\section{Development (Pengembangan)}

Peneliti melakukan tahap development (pengembangan) bertujuan 
untuk mengetahui kevalidan produk melalui uji pakar, meliputi pakar materi, pakar media, dan pakar pembelajaran. Setelah produk jadi maka produk akan diujikan oleh para ahli/pakar. Para ahli/pakar akan memberikan umpan balik berupa kritik dan saran perbaikan sehingga peneliti melalukan revisi sesuai saran pakar. Hal ini dilakukan sebalum produk diujicobakan di lapangan.

\section{Implementation (Implementasi)}

Sebelum produk diujicobakan di lapangan, media akan diujicobakan kepada 5-8 siswa bersama guru tujuannya untuk mengetahui kepraktisan media melalui pengisian instrumen angket yang disebarkan si peneliti. Setelah itu peneliti melakukan penelitian dengan mengujicobakan media pada satu kelas. Pada tahap ini, hasil penilaian kemampuan pemecahan masalah pretest dan posttest serta penilaian presentasi akan dianalisis untuk menentukan keefektifan media pembelajaran.

\section{Evaluation (Evaluasi)}

Peneliti melakukan tahap evaluation dengan cara mengolah data pretest dan posttest kemampuan pemecahan masalah menggunakan SPSS 16.0 for windows untuk dilakukan uji Paired Samples T Test.

\section{Teknik Analisis Data}

Data hasil perhitungan validasi produk yang diperoleh dari pakar kemudian dianalisis menggunakan teknik deskriptif persentase dan kategoris, tujuannya untuk mengetahui kelayakan media yang telah dikembangkan. Skor hasil pengukuran dengan menggunakan angket tertutup lalu dipersentasekan dengan menggunakan rumus

dengan

$$
\mathrm{AP}=\frac{\text { Skor Aktual }}{\text { Skor Ideal }} \times 100 \%
$$

$$
\begin{aligned}
\text { AP }= & \text { Angka Persentase } \\
\text { Skor Aktual = } & \text { Skor yang diberikan } \\
& \text { validator } \\
\text { Skor Ideal = } & \text { Skor maksimal hasil kali } \\
& \text { antara jumlah item } \\
& \text { dengan skor maksimal } \\
& \text { masing- masing item }
\end{aligned}
$$

Rentang angka persentase selanjutnya dikelompokkan menjadi lima kategori yang dapat dilihat pada Tabel 1 .

Tabel 1. Kriteria Penilaian

\begin{tabular}{cl}
\hline Interval & \multicolumn{1}{c}{ Kategori } \\
\hline $81-100 \%$ & Sangat tinggi \\
$61-80 \%$ & Tinggi \\
$31-60 \%$ & Cukup \\
$21-40 \%$ & Rendah \\
$1-20 \%$ & Sangat rendah \\
\hline
\end{tabular}

Berdasarkan rentang angka persentase dan kategori pada Tabel 1, media komik dinyatakan layak dan dapat diujicobakan di lapangan apabila mendapat angka persentasi minimal $61 \%$ dengan kategori tinggi. Kepraktisan dilakukan dengan analisis hasil respon siswa ketika uji coba terbatas media komik. Keefektifan dilakukan dengan analisis komparatif, yaitui membandingkan hasil pembelajaran sebelum dan sesudah penerapan media komik dengan model problem posing untuk satu kelas dengan one grup design pretest-posttest menggunakan kriteria kemampuan pemecahan masalah yang mencakup 5 aspek, meliputi aspek memahami masalah, merencanakan 
penyelesaian, melaksanakan penyelesaian, dan memeriksa kembali. Hasil dari ketiga kriteria digunakan untuk menentukan skor akhir. Skor akhir sebelum dan sesudah penerapan media dibandingkan dengan uji $\mathrm{T}$ sampel berpasangan (Paired Samples T Test) melalui SPSS 16.0 for windows.

\section{HASIL DAN PEMBAHASAN}

Hasil

Penelitian dan pengembangan produk ini menggunakan model pengembangan ADDIE. Model ADDIE. Hasil penelitian dengan 5 tahap tersebut dijelaskan sebagai berikut.

\section{Analysis (Analisis)}

Berdasarkan hasil wawancara dengan guru kelas V SD maka diperoleh data bahwa selama mengajar guru belum pernah mengembangkan media pembelajaran. Guru dalam proses pembelajaran menggunakan berbagai macam cara agar siswa mampu memahami materi yang diajarkan. Selain itu, guru sudah berusaha menggunakan media ketika mengajar seperti media konkrit berupa plastisin (was). Hal ini menunjukkan bahwa belum ada media pembelajaran yang berkaitan dengan aktivitas membaca buku yang didesain dengan perpaduan teks dan ilustrasi gambar berupa komik.

Peneliti juga menyebar angket tentang kemampuan awal siswa dalam menggunakan komik. Hal ini dilakukan guna mengetahui pengalaman siswa ketika membaca buku berupa komik sesuai dengan media pembelajaran yang akan dikembangkan oleh peneliti. Hasil angket menunjukkan bahwa 41 siswa mengenal komik dan mengetahui aturan bacanya. Selain itu, peneliti melakukan identifikasi kemampuan awal siswa dalam materi pecahan pada mata pelajaran matematika. Materi pecahan ini lebih difokuskan pada penjumlahan dan pengurangan pecahan dengan penyebut berbeda.

Berdasarkan hasil angket yang diberikan peneliti, diketahui bahwa siswa Kelas V SD yang berjumlah 41 siswa sudah mengenal penjumlahan dan pengurangan pecahan dengan penyebut berbeda. Langkah selanjutnya peneliti melakukan wawacara singkat dengan beberapa siswa terkait dengan kemampuan pemecahan masalah. Berdasarkan hasil wawancara, siswa belum pernah mengerjakan soal dengan menuliskan langkah-langkah penyelesaian secara runtut. Peneliti mencoba memberikan satu contoh soal cerita mengenai pemecahan masalah dan menanyakan kepada siswa mengenai perencanaan penyelesaian soal serta memeriksa kembali, namun siswa merasa bingung beberapa siswa hanya diam dan siswa lain kembali bertanya kepada peneliti.

\section{Design (Perancangan)}

Langkah pertama yang dilakukan peneliti dalam perancangan yakni menetapkan judul komik yaitu My Daily Activity. Kemudian menyiapkan sumber dari buku maupun referensi lain yang mendukung seperti internet, melakukan identifikasi terhadap Kompetensi Dasar pada aspek kognitif dan aspek keterampilan, melakukan identifikasi pada indikator pencapaian kompetensi serta membuat bentuk penilaian yang 

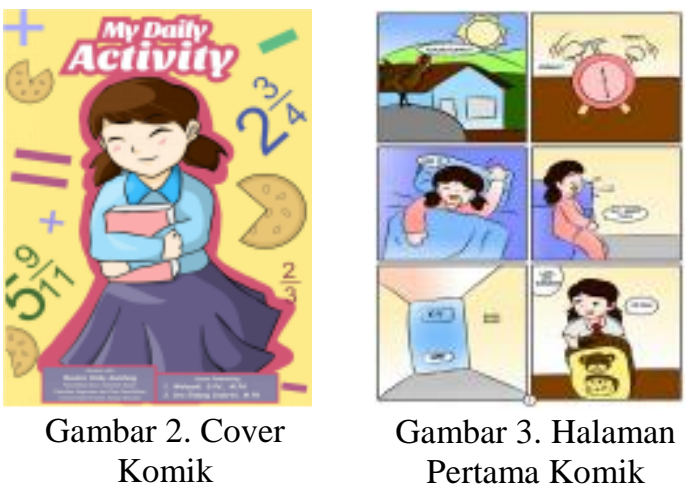

Gambar 3. Halaman Pertama Komik

akan disajikan. Selanjutnya merancang media pembelajaran berupa komik dan menyusun rencana pelaksanaan pembelajaran (RPP) terkait dengan langkah model pembelajaran problem posing. Perancangan dilakukan dengan cara menyusun komik menggunakan beberapa aplikasi yakni medibang dan Corel Draw X7 untuk menghasilkan bentuk desain. Komponen media komik antara lain: kata pengantar, deskripsi media komik, aturan membaca komik, pemetaan Materi, kelas/semester, Kompetensi Dasar, Indikator, penugasan, dan motivasi belajar. Gambar 2-5 adalah contoh tampilan komik yang telah dibuat.

\section{Development (Pengembangan)}

Media pembelajaran yang telah dirancang, selanjutnya akan diuji pakarkan, meliputi pakar materi pembelajaran, pakar media pembelajaran serta pembelajaran. Hasil uji pakar terlihat pada Tabel 2 .

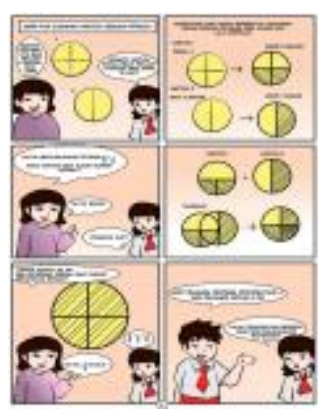

Gambar 4. Halaman Penjelas Penyelesaian Masalah

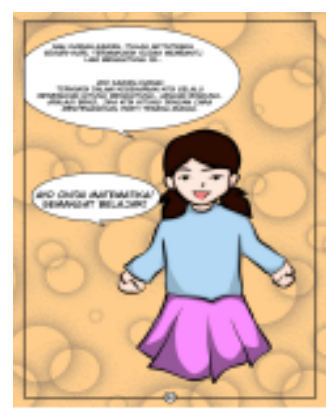

Gambar 5. Halaman Penutup
Berdasarkan kriteria kelayakan media yang dikembangkan oleh peneliti, maka pada indikator materi pembelajaran, media pembelajaran, dan pembelajaran berada dalam kategori tinggi (nilai persentase $\geq 61$ ), sehingga media layak digunakan.

\section{Implementation (Implementasi)}

Peneliti melakukan langkah analisis yakni angket respon siswa dari hasil uji coba terbatas, hasil analisis data dari penilaian kemampuan pemecahan masalah pada masing-masing aspek soal pretest dan posttest, serta hasil penilaian presentasi. Hasil analisis angket respon siswa terlihat pada Tabel 3.

Berdasarkan hasil angket respon siswa uji terbatas diperoleh persentase 91\% siswa dapat menggunakan media komik, sehingga media dapat dikatakan praktis.

Hasil data pemecahan masalah pada saat pretest dan posttest terlihat pada Tabel 4.

Tabel 2. Hasil Penilaian Pakar

\begin{tabular}{lccccc}
\hline No. & Indikator & Skor Ideal & Skor Aktual & AP $(\%)$ & Kategori \\
\hline 1. & $\begin{array}{c}\text { Materi } \\
\text { pembelajaran }\end{array}$ & 55 & 43 & $78 \%$ & Tinggi \\
2. & $\begin{array}{c}\text { Media } \\
\text { pembelajaran }\end{array}$ & 60 & 47 & $78 \%$ & Tinggi \\
3. & Pembelajaran & 60 & 48 & $80 \%$ & Tinggi \\
\hline
\end{tabular}


Tabel 3. Hasil Angket Respon Siswa Uji Coba Terbatas

\begin{tabular}{clc}
\hline No & \multicolumn{1}{c}{ Pernyataan } & Skor \\
\hline 1 & Saya tertarik belajar dengan menggunakan media komik My Daily Activity & 8 \\
2 & Saya senang dapat belajar dengan menggunakan media komik My Daily & 8 \\
& Activity & 6 \\
3 & Saya dapat menjelaskan tentang materi yang ada pada media & 8 \\
4 & Saya mendapat petunjuk penggunaan media & 8 \\
5 & Permasalahan yang ada pada media sering saya temukan di kehidupan & \\
& Sehari-hari & 8 \\
6 & Saya dapat membaca tulisan yang ada pada media & 8 \\
7 & Dengan menggunakan media dapat menambah pengetahuan saya & 8 \\
8 & Saya dapat memahami bahasa yang ada pada media & 6 \\
9 & Saya semakin bersemangat untuk belajar menyelesaikan soal dengan & \\
& pemecahan masalah & 5 \\
10 & Setelah membaca komik My Daily Activity, saya terbiasa menyelesaikan & $\mathbf{7 3}$ \\
& Soal dengan pemecahan masalah & $\mathbf{9 1 \%}$ \\
\hline
\end{tabular}

Tabel 4. Penilaian Kemampuan Pemecahan Masalah

\begin{tabular}{lcccc}
\hline \multirow{2}{*}{\multicolumn{1}{c}{ Aspek }} & \multicolumn{2}{c}{ Pretest } & \multicolumn{2}{c}{ Posttest } \\
\cline { 2 - 5 } & Skor & Persentase & Skor & Persentase \\
\hline Memahami masalah & 119 & $73 \%$ & 140 & $85 \%$ \\
Merencanakan penyelesaian & 61 & $37 \%$ & 132 & $80 \%$ \\
Melaksanakan penyelesaian & 125 & $76 \%$ & 143 & $87 \%$ \\
Memeriksa kembali & 63 & $38 \%$ & 129 & $79 \%$ \\
\hline
\end{tabular}

Hasil data pemecahan masalah pada pretest menunjukkan bahwa ada dua aspek kemampuan pemecahan masalah yang memperoleh persentase kurang dari 50\%, yakni aspek merencanakan penyelesaian dengan persentase sebesar $37 \%$ dan aspek memeriksa kembali dengan persentase sebesar 38\%. Berbeda dengan hasil data pemecahan masalah pada posttest yang menunjukkan semua aspek dalam kemampuan pemecahan masalah memperoleh persentase lebih dari 50\%. Hasil posttest menunjukkan bahwa aspek memahami masalah memperoleh persentase sebesar $85 \%$, aspek merencanakan penyelesaian dengan persentase sebesar $80 \%$, aspek melaksanakan penyelesaian dengan persentase sebesar $87 \%$, dan aspek memeriksa kembali dengan persentase sebesar $79 \%$. Hasil penilaian presentasi kemampuan pemecahan masalah secara rinci disajikan pada Tabel 5.

Tabel 5. Penilaian Presentasi Kemampuan Pemecahan Masalah

\begin{tabular}{|c|c|c|c|}
\hline Kategori & Interval & Frekuensi & Persentase \\
\hline Tinggi & $91-100$ & 7 & $17 \%$ \\
\hline Sedang & $71-90$ & 25 & $61 \%$ \\
\hline Rendah & $61-70$ & 9 & $22 \%$ \\
\hline \multicolumn{2}{|c|}{ Jumlah } & 41 & $100 \%$ \\
\hline
\end{tabular}


Berdasarkan hasil penilaian presentasi kemampuan pemecahan masalah di atas, siswa yang termasuk dalam kategori tinggi sebanyak 7 orang atau sebesar 17\%, kategori sedang sebanyak 25 orang atau sebesar $61 \%$, dan kategori rendah sebanyak 9 orang atau sebesar 22\%. Ilustrasi yang digunakan untuk memudahkan dalam memahami data penilaian presentasi disajikan dalam bentuk diagram pada Gambar 6.

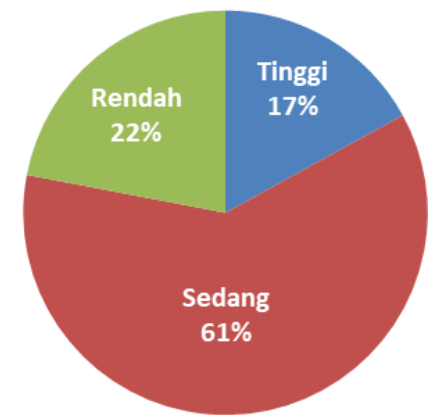

Gambar 6. Diagram Lingkaran Hasil Penilaian Presentasi

\section{Evaluation (Evaluasi)}

Peneliti melakukan tahap evaluasi dengan mengolah data pretest dan posttest menggunakan SPSS 16.0 for windows kemudian dilakukan uji Paired Samples T Test. Langkah yang harus dilakukan yakni Analyze-Compare means-Paired Samples T Test. Hasil uji disajikan pada Tabel 6.

Berdasarkan hasil uji menunjukkan nilai Sig. (2-tailed) sama dengan
0,000 atau kurang dari 0,05 , sehingga dapat dikatakan bahwa terdapat perbedaan yang signifikan antara hasil belajar pada pretest dan posttest.

\section{Pembahasan}

Berdasarkan hasil penelitian, media komik dengan model problem posing dapat meningkatkan kemampuan pemecahan masalah. Hal ini dikarenakan siswa memperoleh kemudahan belajar dalam mengerjakan soal yang diselesaikan menggunakan 4 langkah pemecahan masalah. Sejalan dengan Polya (dalam Wahyudi \& Anugraheni, 2017) menjelaskan bahwa terdapat empat langkah penyelesaian masalah, diantaranya: (1) pemahaman masalah (understanding the problem), (2) perencanaan penyelesaian (devising a plan), (3) melaksanakan perencanaan (carrying out the plan), dan (4) pemeriksaan kembali proses dan hasil (looking back).

Keberhasilan media komik untuk meningkatkan kemampuan pemecahan masalah juga dipengaruhi oleh materi pembelajaran yang disajikan. Pembelajaran ini menggunakan masalah yang sering ditemui dalam kehidupan sehari-hari. Hal ini dapat dijadikan modal utama untuk memecahkan berbagai masalah yang ada dalam kehidupan nyata. Suatu permasalahan

Tabel 6. Uji Paired Samples T Test

\begin{tabular}{|c|c|c|c|c|c|c|c|c|c|}
\hline & & \multicolumn{5}{|c|}{ Paired Differences } & \multirow{3}{*}{$\mathbf{t}$} & \multirow{3}{*}{ df } & \multirow{3}{*}{$\begin{array}{l}\text { Sig. (2- } \\
\text { tailed) }\end{array}$} \\
\hline & & \multirow[t]{2}{*}{ Mean } & \multirow{2}{*}{$\begin{array}{c}\text { Std. } \\
\text { Deviation }\end{array}$} & \multirow{2}{*}{$\begin{array}{l}\text { Std. Error } \\
\text { Mean }\end{array}$} & \multicolumn{2}{|c|}{$\begin{array}{l}\text { 95\% Confidence Interval of } \\
\text { the Difference }\end{array}$} & & & \\
\hline & & & & & Lower & Upper & & & \\
\hline $\begin{array}{c}\text { Pair } \\
1\end{array}$ & $\begin{array}{c}\text { PRETEST } \\
- \\
\text { POSTEST }\end{array}$ & -10.537 & 4.382 & .684 & -11.920 & -9.153 & -15.395 & 40 & .000 \\
\hline
\end{tabular}


yang berhubungan dengan kehidupan sehari-hari, maka dapat mendorong kemampuan siswa dalam menggunakan kecerdasannya yakni memecahkan masalah yang sedang dihadapi. Hal ini sejalan dengan Gadner (dalam Al Maidah, Setyosari, \& Kuswandi, 2017) dimana kecerdasan merupakan kemampuan dalam menyelesaikan masalah maupun menciptakan suatu produk yang berharga dalam lingkungan budaya dan masyarakat. Lebih lanjut, Gadner mengidentifikasi ada delapan kecerdasan meliputi (1) kecerdasan verbal-linguistik mengarah pada kemampuan dalam mengolah kata, (2) kecerdasan logis-matematis yakni kemampuan dalam memecahkan masalah, (3) kecerdasan visual-pasial yakni kemampuan dalam melihat serta mengamati secara cermat, kecerdasan kinestetik yakni kemampuan gerakan tubuh untuk menyampaikan ide dan gagasan, (5) kecerdasan musikal yakni kemampuan yang berhubungan dengan musik seperti kepekaan musik yang didengar, (6) kecerdasan intrapersonal yakni kemampuan dalam memahami perasaan seseorang, (7) kecerdasan interpersonal yakni kemampuan akan kesadaran dan pengetahuan tentang diri sendiri, dan (8) kecerdasan naturalis yakni kemampuan dalam memahami, membedakan, menjelaskan serta membuat kategori yang ditemui di alam sekitar. Delapan kecerdasan yang dimiliki individu akan saling bekerjasama, meskipun setiap individu memiliki taraf kemampuan yang berbeda. Kecerdasan yang lebih ditonjolkan dalam penelitian ini yakni kecerdasan logis-matematis.
Kemampuan pemecahan masalah dapat dimiliki siswa apabila siswa mendapatkan kesempatan yang sama. Oleh karena itu, media komik dirancang melalui pembelajaran dengan menggunakan model problem posing yang memberikan kesempatan siswa dalam aktivitas membaca serta membuat soal dan jawaban yang dilakukan setiap individu dalam kelompok.

Media dirancang dengan cerita yang menimbulkan masalah sehingga antar siswa berlomba-lomba untuk memecahkan masalah serta mendapatkan jawaban yang tepat. Adanya media pembelajaran yang melibatkan kegiatan siswa dengan menikmati ilustrasi gambar serta bacaan, maka siswa lebih tertarik belajar, senang mengikuti pelajaran, mampu menumbuhkan minat baca. Hal ini sejalan dengan salah satu fungsi media pembelajaran yakni memberi suasana belajar yang menyenangkan, tidak tertekan, santai, dan menarik sehingga dapat mencapai tujuan pembelajaran (Sanaky, 2013). Penelitian ini dapat meningkatkan kemampuan pemecahan masalah siswa, yang dapat dibuktikan dengan meningkatnya hasil posttest siswa.

\section{PENUTUP}

Berdasarkan hasil penelitian dan pengembangan (R\&D), dapat disimpulkan bahwa media komik dengan model problem posing dapat meningkatkan kemampuan pemecahan masalah sehingga layak digunakan dalam pembelajaran. Hal ini dapat ditunjukkan dari hasil validasi pakar media, pakar materi, dan pakar pembelajaran yang 
terbukti valid. Keefektifan media ditunjukkan dari hasil belajar siswa berdasarkan Paired Samples $T$ Test dengan Sig (2.tailed) sama dengan 0,000 atau kurang dari 0,05, sehingga hal tersebut dapat dikatakan bahwa adanya perbedaan yang signifikan antara hasil data pretest dan posttest. Kepraktisan media ditunjukkan dari hasil angket respon siswa setelah menggunakan media komik dengan model problem posing dalam pembelajaran dengan persentase $91 \%$.

Peneliti memberikan saran kepada beberapa pihak yang ikut berperan dalam dunia pendidikan. Bagi siswa yang sering melakukan aktivitas membaca buku cerita bertema pendidikan diharapkan dapat menambah pengetahuan melalui kegiatan pembelajaran. Bagi guru, agar dapat memilih dan memanfaatkan media pembelajaran yang sesuai dengan karakteristik siswa serta dapat menumbuhkan minat siswa untuk belajar. Bagi kepala sekolah, agar dapat mempertimbangkan pemanfaatan media pembelajaran yang sesuai dengan karakteristik siswa serta tuntutan pendidikan zaman sekarang. Bagi peneliti selanjutnya, diharapkan dapat mengembangkan produk dari penelitian ini yang sesuai dengan perkembangan zaman, serta mempertimbangkan kelayakan, keefektifan, dan kepraktisan media untuk penelitian selanjutnya.

\section{DAFTAR PUSTAKA}

Al Maidah, A., Setyosari, P., \& Kuswandi, D. (2017). Pengembangan Bahan Ajar Tematik Cetak Semi Digital Berbasis Multiple Intelligences Untuk Siswa KELAS I SD. Seminar Nasional Teknologi
Pembelajaran dan Pendidikan Dasar 2017, 11-16.

Biliya, B. (2015). Penerapan Model Open Ended untuk Meningkatkan Keterampilan Proses dan Hasil Belajar Siswa Kelas V SDN 1 Repaking-Wonosegoro-Boyolali.

Scholaria: Jurnal Pendidikan dan Kebudayaan, 5(1), 78-91.

Inhar, I. (2016). Meningkatkan Hasil Belajar Siswa Kelas VI Melalui Pemelajaran Kooperatif Model Problem Posing Pada Mata Pelajaran IPS Di SDN I Dadakitan. Jurnal Kreatif Tadulako, 4(11).

Istarani. (2015). Model Pembelajaran Inovatif. Medan: Media Persada.

Kemdikbud. (2016a). Kebudayaan. Lampiran Permendikbud Nomor 22 Tahun 2016 Tentang Standar Proses Pendidikan Dasar dan Menengah. Jakarta: Kemendikbud.

Kemdikbud. (2016b). Permendikbud Nomor 24 Tahun 2016 Tentang Kompetensi Inti dan Kompetensi Dasar Kurikulum 2013 pada Pendidikan Dasar dan Menengah. Kemdikbud.

Kuswanti, W. (2016). Penerapan Model Pembelajaran Model Problem Posing Untuk Meningkatkan Aktivitas Dan Hasil Belajar Matematika Siswa Kelas IV A SD Negeri 2 Simpang Agung Tahun Pelajaran 2015/2016. Digital Repository Unila.

Lestari, L., \& Sofyan, D. (2014). Perbandingan Kemampuan Pemecahan Masalah Siswa dalam Matematika antara yang Mendapat Pembelajaran Matematika Realistik (PMR) dengan Pembelajaran Konvensional. Mosharafa: Jurnal 
Pendidikan Matematika, 3(2), 95108.

Mulyati, T. (2016). Kemampuan Pemecahan Masalah Matematis Siswa Sekolah Dasar. Eduhumaniora: Jurnal Pendidikan Dasar, 3(2).

Riska, R., \& MZ, Z. A. (2018). Kemampuan Pemecahan Masalah Matematis dengan Model Pembelajaran Cooperative Integrated Reading and Composition (CIRC) ditinjau dari Kemampuan Awal Matematis Siswa. Journal of Medives: Journal of Mathematics Education IKIP Veteran Semarang, 2(2), 225-233.

Rostika, D., \& Junita, H. (2017). Peningkatan Kemampuan Pemecahan Masalah Siswa SD Dalam Pembelajaran Matematika Dengan Model Diskursus Multy Representation (DMR).
Eduhumaniora: Jurnal Pendidikan Dasar, 9(1), 35-46.

Rusman. (2011). Model-model Pembelajaran: Mengembangkan Profesionalisme Guru. Rajawali Pers/PT Raja Grafindo Persada.

Rusman, R. (2017). Belajar dan Pembelajaran Berorientasi Standar Proses Pendidikan. Jakarta: Kencana Prenada.

Sanaky, H. A. (2013). Media Pembelajaran Interaktif-Inovatif. Yogyakarta: Kaukaba Dipantara.

Wahyudi, \& Anugraheni, I. (2017). Strategi Pemecahan Masalah Matematika. Salatiga: Satya Wacana University Press. 